\title{
KEBIJAKAN 30\% KETERWAKILAN PEREMPUAN DALAM DPRD MENURUT PERSPEKTIF ISLAM
}

\author{
Novianti Soeleman \\ , Khon Kaen University, Thailand \\ Noviyantisoleman6@gmail.com \\ Rifki Elindawati \\ Khon Kaen University, Thailand \\ Rifkielindawati19@gmail.com
}

\begin{abstract}
Abstrak
Indonesia merupakan salah satu negara dengan jumlah penduduk muslim terbanyak di dunia. Indonesia juga bergabung untuk menindaklanjuti kesetaraan gender dan pemberdayaan perempuan. Salah satunya dengan menambah kouta perempuan pada rumah perwakilan rakyat. Dalam kasus Islam, sebagian besar orang percaya bahwa pemimpin haruslah laki-laki. Tujuan penelitian ini adalah untuk pengetahui $30 \%$ perwakilan perempuan bias duduk di DPRD berdasarkan perspektif Islam.
\end{abstract}

Kata kunci: DPRD, Perspektif Islam, Muslim, Pemberdayaan Perempuan

\begin{abstract}
Indonesia is one of the countries with the majority Muslim people in the world. Indonesia also joins to follow up the gender equality and women empowerment. One of the things is by increase the quota of women in house of representative. In case of Islam, most of the people are believe that the leader should be men. To assess this condition, this research aims to know the $30 \%$ women quota house of representative in Indonesia based on Islamic perspective.
\end{abstract}

Keywords: House of representative, Islamic perspective, Muslim, Women empowerment.

\section{A. Pendahuluan}

Pemberdayaan perempuan atau yang biasa disebut dengan women empowerment kini sudah menjadi isu yang layak untuk diperbincangkan. Hampir diseluruh pelosok dunia berlomba lomba untuk melakukan pemberdayaan perempuan di negaranya dalam 
berbagai bidang pekerjaan. Kini mata dunia sudah lebih terbuka mengenai pemberdayaan perempuan.

Perserikatan Bangsa-Bangsa United Nation sendiri memiliki badan mengenai pemberdayaan perempuan yang diberi nama UN Women. UN Women berdiri sebagai bentuk promosi atas kesetaraan gender dan pemberdayaan perempuan (UN Women). Hal tersebut tertuang jelas dalam resolusi general assembly United Nation pada 2 July 2010 yang mana menjelaskan bahwa UN entity pemberdayaan perempuan dan kesetaraan gender atau yang dinamankan UN Women beroperasi per tanggal 1 january 2011 (United Nations, 2010).

Selain itu, pemberdayaan perempuan juga disebutkan langsung dalam Millennium Development Goals (MDGs) pada poin nomor 3 yang berbunyi to promote gender equality and empower women atau untuk mempromosikan kesetaraan gender dan juga pemberdayaan perempuan. Berdasarkan data MDGs, kesetaraan gender serta pemberdayaan perempuan Indonesia menfokuskan pada 3 poin utama yaitu pendidikan, lapangan pekerjaan dan keterwakilan dalam parlemen. Dari ketiga poin tersebut, keterwakilan dalam parlemen merupkan poin dengan hasil yang masih kurang (UNDP, 2008).

Sepanjang sejarah Indonesia, keterlibatan perempuan dalam pengambilan keputusan perlahan lahan mulai terlihat jelas, meskipun asumsi publik mengenai kodrat perempuan yang hanya bisa menjadi ibu rumah tangga masih saja diterapkan. Bukti yang sangat amat jelas adalah presiden ke-lima Indonesia yaitu Dr. (H.C.) Hj. Dyah Permata Megawati Setyawati Soekarnoputri atau yang lebih dikenal dengan sebutan "Mbak Mega". Beliau merupakan puteri dari Ir. Soekarno atau presiden pertama Indonesia. Rupanya jiwa kepemimpinan yang dimiliki sang bapak mengalir ke darah perempuan yang sempat menjadi ketua umum PDIP.

Adapun salah satu role of model perempuan Indonesia yang berhasil menorehkan prestasi hingga tingkat dunia. Beliau adalah Sri Mulyani Indrawati yang mana merupakan salah satu ahli ekonomi Indonesia yang kini menjabat sebagai Menteri Keuangan Indonesia sejak 2016. Sri Mulyani pernah menjadi bagian dari Bank Dunia selaku Managing Director dan Chief Operating Officer. Beliau pun tak jarang menjadi perwakilan Bank Dunia dalam G20.

Dua sosok diatas menunjukan bagaiman pemberdayaan perempuan di Indonesia yang meningkat dari tahun ke tahun. Meskipun begitu, keduanya tetap menjalankan kodratnya sebagai perempuan yang mana menjadi istri bagi suami serta ibu bagi anak anaknya. Selain dua sosok diatas, masih banyak sosok perempuan yang juga menjadi contoh dalam pemberdayaan perempuan di Indonesia.

Akan tetapi keterwakilan perempuan masih belum menunjukan angka yang signifikan, hal ini disebabkan oleh hambatan yang ada. Menurut Matland dalam 
Parawansa, faktor yang mempengaruhi pola seleksi perempuan untuk menjadi anggota parlemen adalah budaya, proses seleksi parpol, media serta dukungan dari luar. Budaya yang dianut orang Indonesia masih sangat patriarki yang mana laki laki lebih berperan lebih dibanding perempuan, proses seleksi parpol masih sangat didominasi oleh kaum laki laki, media masa juga belum terlalu mendukung menyuarakan bagaimana pentingnya keterwakilan perempuan dan yang terakhir adalah dukungan LSM, organisasi serta partai politik (Parwansa).

Undang Undang Nomor 10 Tahun 2008 tentang pemilihan umum mengatur tentang porsi keterwakilan perempuan dalam pemilihan umum dewan perwakilan rakyat. Dalam pasal 53 dengan jelas menyebutkan bahwa daftar bakal calon sebagaimana dimaksud dalam Pasal 52 memuat paling sedikit 30\% (tiga puluh perseratus) keterwakilan perempuan (DPRI, 2008). Sebelumnya berdasarkan data pemilu 1955 hingga 1999 yang dikeluarkan sekretarian DPR pada tahun 2001, persentase keterwakilan perempuan dalam DPR RI paling banyak hanya mencapai angka 13\% yaitu pada tahun 1987-1992.

Berdasarkan data yang dikeluarkan Pew Forum pada tahun 2010, Indonesia merupakan salah satu negara dengan jumlah Muslim terbesar di dunia yaitu sekitar 209 juta jiwa atau 13\% dari populasi muslim dunia (Pew Research Center, 2015). Hal ini menandakan bahwa masyarakat Indonesia kebanyakan akan bertindak dalam perspektif kepercayaannya yaitu Islam. Lalu bagaimana dengan kebijakan keterwakilan perempuan yang ditingkatkan hingga 30\% di parlemen Indonesia sedangkan Quraan Surah An Nissa ayat 34 menyebutkan bahwa kaum laki laki itu adalah pemimpin bagi kaum perempuan dan sebagaian besar rakyat Indonesia mempercayai hal tersebut.

\section{B. Pembahasan}

\section{Teori Pemberdayaan Perempuan}

Menurut Sumarto (2009), partisipasi merupakan proses ketika warga sebagai individu maupun kelompok sosial dan organisasi, mengambil peran dalam proses perencanaan, pelaksanaan dan pemantauan kebijakan-kebijakan yang langsung mempengaruhi kehidupan mereka. Sedangkat Rajput (2001) menjelaskan bahwa pemberdayaan perempuan merupakan salah satu hal penting dalam segala aspek, salah satunya yaitu aspek politik. Aspek politik tersebut akan menjadi fondasi untuk kesetraan gender dan juga kemajuan bagi kaum perempuan. Dengan adanya pemberdayaan perempuan dapat meningkatkan efektifitas, kapasitas, dan menantang struktur kekuasaan maupun ideologi patriarki yang tertanam dinegara tersebut (Mandal, 2013).

\section{Pandangan Islam Mengenai Keterwakilan Perempuan dalam DPRD}

Islam merupakan salah satu kepercayaan atau agama yang sangat memuliakan perempuan. Bahkan dalam islam, perempuan lebih istimewa dibandingkan laki laki. 
Dalam islam, perempuan haruslah dihargai dan diperlakukan sebaik mungkin. Sejarah mengatakan kehadiran Islam juga untuk memngangkat derajat perempuan yang sempat direndahkan pada masa jahiliyah.

Kemuliaan perempuan dalam Islam tidak mengenal status dan umur. Islam memuliakan perempuan dari anak anak hingga menjadi istri dan ibu, bahkan islam juga memuliakan perempuan yang menjadi janda. Hal ini menunjukkan bahwa sesungguhnya Islam memuliakan perempuan tanpa memandangan bulu. Berikut ini adalah beberapa ayat quran serta hadits atau sunnah mengenai kemuliaan perempuan.

- $\quad$ An-Nahl ayat 58 \& 59

Padahal apabila seseorang dari mereka diberi kabar dengan (kelahiran) anak perempuan, wajahnya menjadi hitam (merah padam), dan dia sangat marah. Dia bersembunyi dari orang banyak, disebabkan kabar buruk yang disampaikan kepadanya. Apakah dia akan memeliharanya dengan (menanggung) kehinaan atau akan membenamkannya ke dalam tanah (hidup-hidup)? Ingatlah alangkh buruknya (putusan) yang mereka tetapkan itu.

- HR Muslim

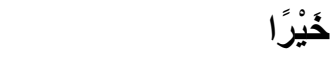

Menyuarakan untuk berbuat baik dan memperlakukan perempuan dengan baik.

Dari kedua ayat serta hadits diatas menunjukkan bagaimana kemuliaan perempuan dimata Islam. Bahkan semua orang disarankan untuk memperlakukan perempuan dengan baik sebagaimana mestinya. Lalu bagaimana dengan kedudukan $30 \%$ perempuan dalam parlemen Indonesia sesuai dengan apa yang direncanakan Islam? Apakah hal ini berarti bertolak belakang dengan apa yang diatur dalam Islam?.

Di lain sisi, pemerintah Indonesia masih gencar gencarnya mengejar angka 30\% untuk keterwakilan perempuan. Pemerintah Indonesia melakukan segala upaya untuk memenuhi angka tersebut. Bahkan partai politik pun ikut berupaya memenuhi angkat tersebut mulai dari tingkat daerah hingga nasional.

Namun beberapa ayat al quran serta sunnah dan hadits juga memberikan penjelasan yang mengarah kepada kepemimpinan perempuan. Hal yang sangat umum adalah dalam pembagian warisan, perempuan juga mendapatkan bagian dalam pembagian warisan. Tidak hanya laki laki saja yang berhak atas hal tersebut. Dalam ayat An Nisa ayat 7, menyatakan bahwa perempuan juga memiliki hak mendapatkan peninggalan orangtuanya selain laki laki dan porsinya telah ditentukan. Melalui surah tersebut dapat ditafsirkan bahwa posisi perempuan juga memiliki hak yang sama dengan laki laki.

Al Hujurat: 13 yang berbunyi "Wahai manusia! Sungguh, Kami telah menciptakan kamu dari seorang laki-laki dan seorang perempuan, kemudian Kami 
jadikan kamu berbangsa-bangsa dan bersuku-suku agar kamu saling mengenal. Sesungguhnya yang paling mulia di antara kamu di sisi Allah ialah orang yang paling bertakwa. Sungguh, Allah Maha Mengetahui, Mahateliti."

Dari ayat tersebut dapat diartikan bahwa sesungguhnya kedudukan perempuan dan laki laki dimata Allah SWT adalah tidak ada bedanya. Yang membedakan manusia dimata Allah SWT hanyalah ketakwaan yang dimiliki. Dari tafsiran tersebut dapat sedikit membantu tentang kesempatan perempuan yang sama dengan laki laki dalam parlemen. Karena yang terpenting adalah ketakwaan maka yang menjadi poin adalah bagaimana seseorang menjalankan tugas yang sesuai dan tidak melanggar larangan Allah SWT.

Selanjutnya adalah HR Bukhori dari Abu Bakrah yang menjelaskan bahwa nasib suatu kaum tidak akan beruntung jika berada dibawah kepemimpinan perempuan. Hadits ini mengarahkan bahwa sesungguhnya perempuan tidak akan membawa keberuntungan bagi kaum sehingga sebaiknya tidak memipin agar nasib kaum tersebut tidak buruk.

Meskipun demikian, yang harus digaris bawahi adalah kata "memimpin". Dalam hadits tersebut tidak dijelaskan secara jelas bentuk kepemimpinan yang dimaksud, kepemimpinan hanya ditulis secara umum. Untuk itu harus dikaji lebih dalam mengenai makna kepemimpinan yang dimaksudkan. Apakah pemimpin keluarga? Pemimpin suatu negara? Ataukah pemimpin suatu umat yaitu umat islam?

Kata pemimpin dan kepemimpinan dalam islam dikenal dengan istilah khilafah. Dalah Al-Quran telah dijabarkan bahw asesungguhnya manusia yang ada dimuka bumi adlaah khalifah. Surah Al-Baqarah 30 yang lebih memperjelas tentang manusia sebagai khalifah dimuka bumi sebagaimana yang telah diatur Allah SWT. Dari sini dapat ditarik hubungan bahwa memimpin merupakan salah satu amanah dari Allah SWT.

Kepemimpinan Islam menurut tafsir al-Mishbah oleh M. Quraish Shihab adalah pemimpin yang disesuai dengan syariat maupun aturan dalam Islam. Prinisp kepemimpinan diantaranya adalah tauhid, kesederhanaan, tanggung jawab, musyawarah, adil dan juga kebebasan berfikir (Supyan, 2013).

Konsep kepemimpinan dalam Islam pun tidak begitu jelas dalam menafsirkan makna pemimpin yang dimaksudkan. Lalu apakah anggota parlemen termasuk dalam pemimpin? Tentu saja tidak jika dilihat secara garis besar. Karena secara langsung maupun tidak langsung anggota parlemen tidak memimpin hanya saja menjadi bagian dalam pembuat keputusan.

Pendapat lainnya datang dari mufti besar Mesir, Dr. Muhammad Sayid Thanthawi yang menjelaskan bahwa dalam kepemimpinan perempuan maupun menduduki jabatan di parlemen tidak bertentangan dengan syariah Islam. Hal tersebut juga didukung oleh fatwa Qardawi yang menyatakan bahwa perempuan memiliki 
tamam al ahliyah atay kemampuan sempurna. Hanya saja yang perlu diingat adalah perempuan tidak bisa menduduki jabatan seperti Syaikh Al-Azhar atau yang berhubungan dengan imam shalat.

Syaikh Yusuf al Qardawi dalam Fiqih Daulah menjabarkan kondisi yang memperbolehkan perempuan menduduki posisi parlemen. Diantaranya adalah perempuan yang memiliki kelebihan, kemampuan, kecerdasan, memiliki banyak waktu luang, tetap berpegang pada aturan Islam dan serta tidak mengganggu pekerjaan utamanya sebagai perempuan baik istri maupun sebagai seorang ibu.

Adapun yang perlu dijadikan pertimbangan adalah porsi perempuan dalam parlemen. Pemerintah Indonesia hanya menargetkan pencapaian angka $30 \%$, menandakan bahwa antara perempuan dan laki laki perbandingannya 3:7. Berarti bahwa laki laki masih mendominasi dan dapat dikatakan bahwa perempuan tidak memimpin secara keseluruhan dengan porsi yang sangat sedikit.

\section{Simpulan}

Pemberdayaan perempuan merupakan suatu hal yang penting dimasa kini. Selain untuk menepis budaya patriarki yang terjadi dimasyarakat, pemberdayaan perempuan juga menjadi suatu alat untuk memajukan kaum perempuan sesuai dengan hak asasi manusia. Salah satu bentuk pemberdayaan perempuan yang dilakukan di Indonesia adalah dengan menetapkan target $30 \%$ porsi perempuan dalam parlemen. Islam adalah negara yang sangat mengistimewakan perempuan bahkan Islam sendiri memerintah manusia untuk menghargai perempuan sebagaimana mestinya. Namun konsep pemberdayaan perempuan itu sendiri menjadi perdebatan jika dikaitkan dengan kepemimpinan perempuan yang ada karena dianggap bertentangan dengan Islam. Setelah ditelusuri ternyata ada beberapa hal yang juga penting untuk dipertimbangkan mulai dari konsep pemimpin itu sendiri hingga istimewanya perempuan. Berdasarkan konsep pemimpin Islam, kedudukan perempuan dalam parlemen tidak dikategorikan sebagai pemimpin yang dimaksudkan dalam Quran maupun Hadits. Sehingga dapat ditarik kesimpulan bahwasannya kebijakan 30\% perempuan dalam parlemen tidak melanggar aturan Islam.

\section{Referensi}

Dewan Perwakilan Rakyat Republik Indonesia. (2008). UNDANG-UNDANG REPUBLIK INDONESIA NOMOR 10 TAHUN 2008. Retrieved from DPR RI: http://www.dpr.go.id/dokjdih/document/uu/UU_2008_10.pdf.

Dirjosisworo, S. (1999). Megawati Dalam Babar Sejarah Pemimpin Perempuan indonesia. Bandung: Mandar Maju. 
Hetifah Sj, S. (2009). Inovasi, Partisipasi, dan Good Governance. Jakarta: Yayasan Obor Indonesia.

Mandal, K. C. (2013). Concept and Types of Women Empowerment. International Forum of Teaching and Studies, 9, 22.

Parawansa, K. I. (n.d.). Hambatan Terhadap Partisipasi Politik Perempuan di Indonesia. Retrieved from AMAZONAWS: https://s3.amazonaws.com/academia.edu.documents/37076367/BAHAN_MATE RI_.pdf?AWSAccessKeyId=AKIAIWOWYYGZ2Y53UL3A\&Expires=154453 4319\&Signature $=\mathrm{MjBO} 1 \mathrm{Wa6FiG5zmCCmjuyK78f \% 2Fw4 \% 3D \& response-}$ contentdisposition=inline\%3B\%20filename\%3DHambatan_terhadap_Partisipasi_.

Pew Research Center. (2015). Muslims. Retrieved from The Future of World Religions: Population Growth Projections, 2010-2050: http://www.pewforum.org/2015/04/02/muslims/.

Qardhawi, Y. A. (n.d.). Fiqh Daulah.

Supyan, M. D. (2013). Kepemimpinan Islam dalam tafsir Al-Mishbah karya M. Quraish Shihab. Yogyakarta: Fakultas Dakwah Universitas Islam Negeri Sunan Kalijaga.

UN WOMEN. (n.d.). About Us. Retrieved from UN WOMEN: http://www.unwomen.org/en/about-us.

UNDP. (2008). Millenium Development Goals. Retrieved from UNDP: http://www.id.undp.org/content/dam/indonesia/docs/MDG/Let\%20Speak\%20Ou t\%20for\%20MDGs\%20-\%20ID.pdf.

United Nations. (2010, July 2). General Assembly. Resolution adopted by the General Assembly on 2 July 2010 , p. 8.

WORLD BANK. (n.d.). Featured Speaker. Retrieved from World Bank Live: https://live.worldbank.org/experts/sri-mulyani-indrawati. 